УДК: 004.422.83

Андрій Корецький, кандидат військових наук, старший науковий співробітник Національний університет оборони України імені Івана Черняховського, м. Київ

ORCID ID 0000-0002-6346-3083

Сергій Горбачевський, кандидат технічних наук, старший науковий співробітник Національний університет оборони України імені Івана Черняховського, м. Київ

ORCID ID 0000-0002-4946-1604

Людмила Наливайко, Національний університет оборони України імені Івана Черняховського, м. Київ

ORCID ID 0000-0002-2240-5135

DOI: $10.33099 / 2617-1775 / 2021-02 / 108-114$

\title{
ПРОБЛЕМНІ ПИТАННЯ ІНФОРМАЦІЙНОГО ЗАБЕЗПЕЧЕННЯ НАУКОВОЇ І НАУКОВО-ТЕХНІЧНОЇ ДІЯЛЬНОСТІ У ВВНЗ
}

Розглянуто структуру інформаційного забезпечення (I3) наукової і науково-технічної діяльності у ВВНЗ, основні проблемні питання IЗ та шляхи їх вирішення.

Ключові слова: інформаційна система; інформаційне забезпечення; наукова і науковатехнічна діяльність; вищі військові навчальні заклади.

Постановка проблеми. Інформаційне забезпечення $є$ одним 3 основних видів забезпечення наукової i науково-технічної діяльності (ННТД). Тому аналіз стану інформаційного забезпечення ННТД та усунення проблемних питань I3 є вкрай актуальним завданням. Інформаційне забезпечення ННТД це комплекс організаційно-технічних заходів спрямованих на задоволення потреб суб’єктів наукової діяльності в інформації, необхідній для створення наукової (науково-технічної) продукції. I3 ННТД здійснюється за видами науково-інформаційної діяльності, до якої належать: збирання, обробка, зберігання, оновлення i поширення інформації [1]. У сучасному інформаційному середовищі перерахованих видів науково-інформаційної діяльності вже стає недостатньо [2]. Для ефективного виконання I3 свого призначення необхідно додати, щонайменше, систематизацію та аналіз інформації. Структурно ІЗ ННТД можна розділити на бібліотеки (репозіторіі), пошукові системи, ПЕОМ науковців як інструмент доступу та переробки наукової інформації, сервери, програмне забезпечення, мережі зв'язку, доступ до наукометрічних та інших наукових баз та таке інше.

Аналіз публікацій. Питанням інформаційного забезпечення системи управління науковими проектами у вищих військових навчальних закладах присвячені дослідження Р.В. Булгакова та В.Г. Голованя [2], О.М. Перегуди, О.П. Черкеса, П.М. Піонтківського, О.В. Дзюбенка [3], В.М. Міхайленко, Т.В. Січко [4].

Метою статті $\epsilon$ аналіз проблемних питань інформаційного забезпечення 
ННТД у ВВНЗ та напрацювання пропозицій щодо його удосконалення.

Виклад основного матеріалу. Наукову і науково-технічну діяльність можна умовно поділити на науково-організаційну роботу та власне наукову роботу. Тому розглянемо окремо проблемні питання інформаційного забезпечення науковоорганізаційної та наукової роботи.

Науково-організаційна діяльність - діяльність, спрямована на методичне, організаційне забезпечення та координацію наукової, науково-технічної та науково-педагогічної діяльності (ВР України, Закон "Про наукову і науковотехнічну діяльність" від 26.11.2015 N 848-VIII [5]). Зазвичай у наукових закладах є окремі підрозділи, які займаються науково-організаційною діяльністю відповідно до основних форм ННТД. Основними формами ННТД є науково-дослідні та дослідно-конструкторські роботи (ДКР), оперативні завдання, підготовка науковопедагогічних кадрів, проведення науково-практичних конференцій, семінарів тощо, підготовка до видання монографій, підручників та посібників, підготовка статей, зокрема до наукових видань, які індексуються у Scopus, Web of Science тощо.

Основними функціями науково-організаційної діяльності $\epsilon$ організація планування, координація виконання ННТД та облік результатів 3 можливістю формування інформаційно-аналітичних довідок.

Аналіз стану інформаційного забезпечення науково-організаційної діяльності, проведений на прикладі Національного університету оборони імені Івана Черняховського, показав, що основними проблемними питаннями є:

не достатній рівень забезпечення сучасними ПЕОМ;

низькій рівень автоматизації обліку результатів ННТД.

I якщо першу проблему можна вирішити досить швидко шляхом закупівлі відповідних ПЕОМ, то розробка спеціального програмного забезпечення для автоматизації обліку результатів ННТД потребує часу та об'єднання зусиль фахівців всіх ВВНЗ.

Наразі можна стверджувати, що рівень автоматизації цих процесів поки мізерний. У ліпшому разі це таблиці в Excel. Приклад обліку ID науковців авторів видань, які індексуються у Scopus, Web of Science тощо наведено на рис. 1.1, приклад обліку здобутків окремого науковця наведено на рис. 1.2.

\begin{tabular}{|c|c|c|c|c|c|}
\hline \multicolumn{2}{|c|}{ 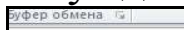 } & Шрифт & выравнивание & \multicolumn{2}{|r|}{ Редактир ова } \\
\hline \multicolumn{2}{|c|}{ D170 } & \multicolumn{2}{|c|}{\begin{tabular}{l|l}
$f_{x}$ & 36081457300 \\
\end{tabular}} & \multirow[b]{2}{*}{ D } & \multirow[b]{2}{*}{$\mathrm{E}$} \\
\hline$\Delta$ & A & B & C & & \\
\hline 153 & 138 & цвсд & Бойко Руслан Васильович & $\underline{57218620434}$ & \\
\hline 154 & 139 & цвсд & Котляренко Олександр Петрович & $\underline{57209581496}$ & \\
\hline 155 & 140 & цвсд & Приполова Людмила Іванівна & $\underline{57219164218}$ & \\
\hline \multicolumn{6}{|l|}{156} \\
\hline 157 & 141 & ннцфпсот & Петрачков Олександр Валерійович & $\underline{57218622265}$ & \\
\hline 158 & 142 & ннцфпсот & Кувшинов Олексій Вікторович & $\underline{57207859604}$ & \\
\hline 159 & 143 & ннцфпсот & Ягупов Василь Васильович & $\underline{57217104620}$ & AAR-7554-2020 \\
\hline 160 & 144 & ннцфпсот & Мартиросян Артур Артурович & $\underline{57194710415}$ & \\
\hline 161 & 145 & ннцфпсот & Вербин Назарій Борисович & $\underline{57218623158}$ & \\
\hline 162 & 146 & ннцфпсот & Оленєв Дмитро Геннадійович & $\underline{57202817103}$ & $\underline{\mathrm{AAH}-7472-2020}$ \\
\hline 163 & 147 & ннцфпсот & Шемчук Вадим Андрійович & $\underline{57217487221}$ & \\
\hline 164 & 148 & ннцфпсот & Свистун Валентина Іванівна & $\underline{57210751521}$ & $\underline{\mathrm{AAH}-4975-2021}$ \\
\hline 165 & 149 & ннцфпсот & Кива Владислав Юрійович & $\underline{57217158451}$ & AAD-7020-2019 \\
\hline 166 & 150 & ннцфпсот & Височіна Надія Леонідівна & $\underline{57201430337}$ & $\underline{\mathrm{G}-8854-2018}$ \\
\hline 167 & 151 & ннцфпсот & Бабак Світлана Віталіївна & $\underline{57215218483}$ & \\
\hline
\end{tabular}

Рис. 1.1 - Облік ID науковців авторів видань, які індексуються у Scopus, Web of Science в Excel 


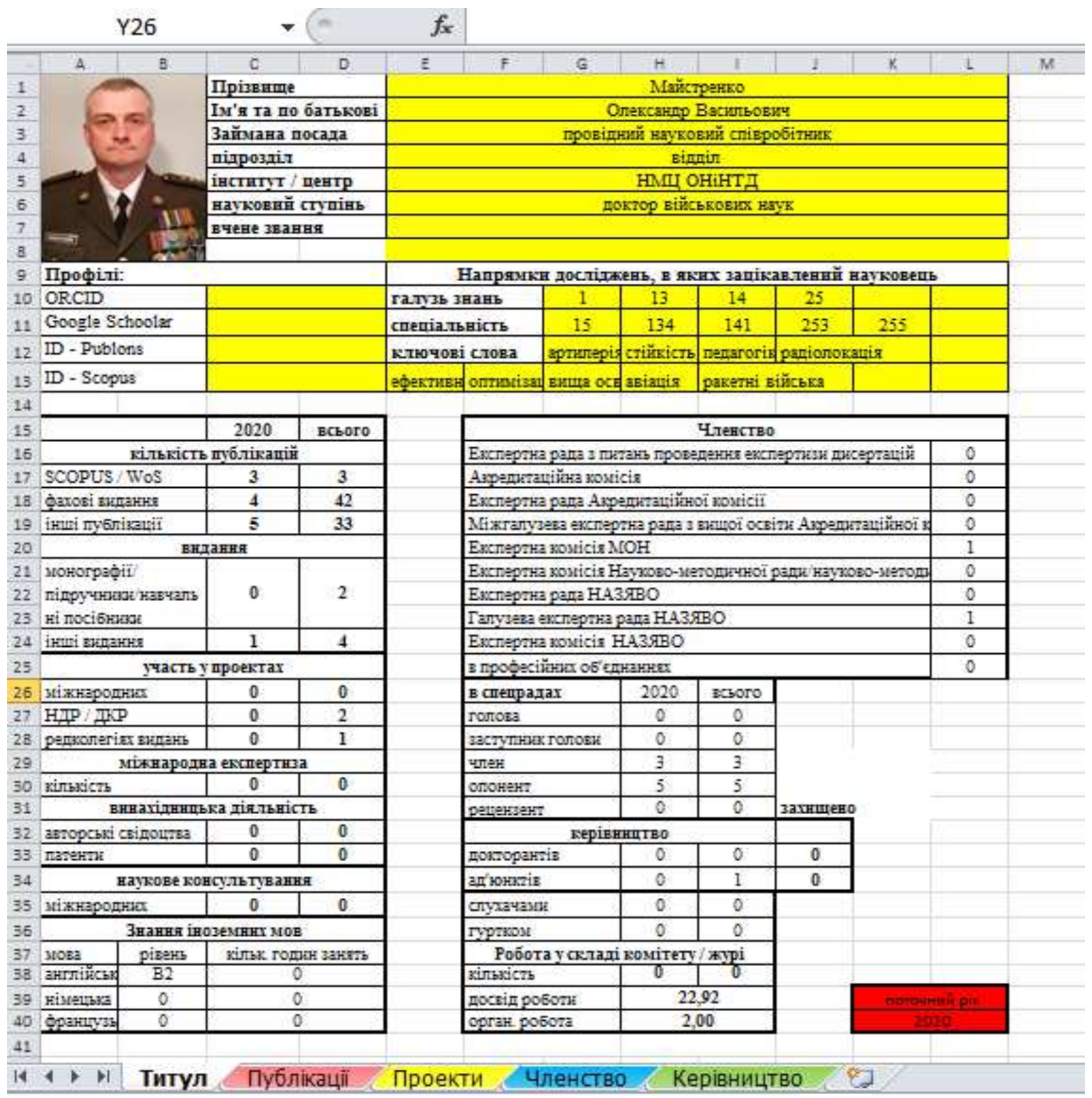

Рис. 1.2 - Облік здобутків окремого науковця в Excel

Облік у Excel результатів ННТД має свої недоліки та переваги.

\section{Недоліки ведення обліку у Excel}

неможливість одночасно працювати з одним документом двом і більше працівникам;

необхідність вручну проводити консолідацію даних, через що зростає ризик виникнення помилок;

немає гарантії збереження і безпеки даних, особливо, якщо з документами можуть працювати кілька співробітників, немає логування та системи повідомлень користувачам;

проблема контролю введення даних;

низька продуктивність, особливо під час роботи з пов'язаними таблицями; необхідність вручну створювати таблиці для кожного облікового періоду.

\section{Переваги ведення обліку у Excel:}

гнучкість структури даних, можливість модифікації “на льоту”; 
швидкість початку роботи (можна відразу починати працювати зі створеними таблицями та у процесі роботи допрацьовувати структуру даних);

знайомий більшості користувачів інтерфейс (достатньо описати, що куди вносити і можна починати працювати);

не потрібна інфраструктура, вистачить ПЕОМ або безкоштовного Google Disk для роботи в хмарі - просто заводимо аккаунт і починаємо працювати. Не потрібно нічого встановлювати та робити бекапи даних, не потрібні ніякі початкові установки і настройки.

Зрозуміло, що у XXI сторіччі потрібно впроваджувати облікові системи на кшталт 1C, SAP, які мають бути інтегровані з автоматизованими системами управління ВВНЗ [6].

Тобто сучасна інформаційна система ННТД (IC ННТД) має бути частиною єдиного інформаційного середовища ВВНЗ, органів та підрозділів управління ННТД та забезпечувати автоматизацію процесів ННТД.

Завдання IC ННТД щодо науково-організаційної діяльності:

забезпечення електронного документообігу щодо ННТД;

забезпечення швидкої та зручної комунікації учасників ННТД;

забезпечення обліку науковців та обладнання для досліджень;

забезпечення автоматизованого отримання, реєстрації, обліку, збереження інформації щодо ННТД;

забезпечення автоматизованих розрахунків за типовими методиками (завантаженість науковців, бюджет НДР, фонд робочого часу, кращий науковець (підрозділ) та ін.) для формування відповідних документів (звітів, довідок, витягів тощо);

створення внутрішнього інформаційного ресурсу та забезпечення швидкого i зручного доступу учасників ННТД до необхідної інформації (відповідно до категорій користувачів);

забезпечення захисту інформації, що використовується в IC ННТД відповідно до вимог чинного законодавства.

\section{Переваги виростання автоматизованих систем обліку:}

1. Усі дані зберігаються у єдиній реляційній базі даних, наприклад, SQL Server.

2. У кожного користувача свій веб-інтерфейс тільки з тими функціями i можливостями, які йому необхідні для роботи. Це особистий кабінет користувача в системі.

3. Основа інтерфейсу - це дашборди, форми і таблиці. Дашборди дають загальне розуміння щодо сучасного стану. Таблиці дають змогу швидко знаходити потрібні дані через фільтри. Форми - вводити дані в максимально простому вигляді для оператора.

4. Доступ до особистого профілю можливий з ПЕОМ, планшета, телефону. Ключові функції доступні в будь-який момент часу (вдома, в дорозі, в офісі).

5. Користувач отримує повідомлення про найважливіші події в системі у вигляді пуш-повідомлень на телефон, або в самій системі (внутрішня система повідомлень).

6. Система має змогу інтеграції з іншими зовнішніми системами, щоб 
зменшити ручну працю, прискорити операції і мати можливість більш щільно працювати 3 документами у команді. Для окремих груп користувачів можна створювати свої спеціальні особисті кабінети з обмеженими функціями.

Щодо проблемних питань інформаційного забезпечення безпосередньо наукової роботи, то до них можна віднести:

не достатній рівень забезпечення сучасними ПЕОМ;

відсутність відомчих інформаційних систем забезпечення ННТД.

Істотною особливістю воєнно-наукових досліджень $є$ наявність інформації 3 обмеженим доступом, а тому для іiі збереження потрібно створювати комплексну систему захисту інформації. Щодо накопичення і обробки відкритої наукової інформації, то 3 цім більш менш справляється Національний репозитарій академічних текстів, хоча до нього не попадає цілий пласт наукових досліджень у вигляді оперативних завдань. Іноді оперативні завдання за обсягом досліджень дорівнюють НДР. Решта специфічних досліджень у системі Міністерства оборони України, таких як НДР (ДКР) та дисертації 3 грифом обмеження доступу, результати випробувань та результати досліджень на заходах оперативної підготовки мають обмеження в доступі і саме тому потрібно створювати контур збереження, накопичення та обліку науковотехнічної інформації з обмеженим доступом.

Стан інформаційного забезпечення ННТД ВВНЗ був би якіснішим, якщо би у ВВНЗ упроваджувались автоматизовані системи управління ВВНЗ. Нажаль у ВВНЗ, на відміну від цивільних ЗВО та закладів МВС - Національної гвардії та Погранслужби, на сьогодні автоматизовані системи управління навчальним закладом у ВВНЗ відсутні.

Ще одною вадою створення сучасної системи інформаційного забезпечення ННТД є нестача кваліфікованих кадрів, особливо спеціалістів 3 інформаційних технологій та програмістів. Тому ВВНЗ мали би об'єднувати зусилля щодо робіт з інформаційного забезпечення ННТД та обміну досвідом у цьому питанні. Організаційно це міг би бути постійно діючий семінар або регулярна науково-практична конференція. Окремі зусилля у цьому напрямку вже $\epsilon$. Так у 2021 році відбувся вебінар з питань впровадження автоматизованої системи управління навчальним закладом у Національній академії прикордонної служби України ім. Б. Хмельницького.

Висновки. Сучасний стан розвитку науки вимагає максимального впровадження сучасних технологій в систему інформаційного забезпечення ННТД у ВВНЗ. Така автоматизація дозволить як підвищити якість управлінських рішень щодо ННТД, так і забезпечити простий і зручний доступ науковців до інформації, можливість спільної роботи над науковими проектами.

Напрями подальших досліджень пов'язані 3 впровадженням автоматизованих інформаційних систем у повсякденну діяльність науковців.

\section{ЛІТЕРАТУРА}

1. Наказ Міністерства оборони України від 27.09.2016 р. № 385 “Про затвердження Положення про організацію наукової і науково-технічної діяльності у Збройних Силах 
України // [Електронний ресурс] Режим доступу: http://zakon.rada.gov.ua/laws/show/1172-16.

2. Булгаков Р.В., Головань В.Г., Перспективна модель інформаційного забезпечення системи управління науковими проектами у вищих військових навчальних закладах. Збірник наукових праць Військової академії, 2019. № 1 (11). С. 130-136.

3. О. М. Перегуда, О. П. Черкес, П. М. Піонтківський, О. В. Дзюбенко Методика вибору та впровадження інформаційної системи в діяльність вищого військового навчального закладу. Збірник наукових праць ЖВІ. 2019. Випуск 17. С. 41-51

4. ВМ Міхайленко, ТВ Січко Моделі і методи автоматизованої системи управління регіонального університетського центру. Монографія.-Вінниця: ВНАУ, 2014.-184 с.

5. Закон України "Про наукову та науково-технічну діяльність"// [Електронний ресурс] Режим доступу: http://zakon.rada.gov.ua/laws/show/848-19.

6. Горбачевський С., Орда М., Напрямки використання сучасних технологій в інформаційному забезпеченні системи військової освіти/ Збірник наукових праць “Військова освіта”- №1 (41), - 2020. - С. 103-109.

\section{REFERENCES}

1. Nakaz Ministerstva oborony Ukrainy vid 27.09.2016 r. № 385 "Pro zatverdzhennia Polozhennia pro orhanizatsiiu naukovoi i naukovo-tekhnichnoi diialnosti u Zbroinykh Sylakh Ukrainy // [Elektronnyi resurs] Rezhym dostupu: http://zakon.rada.gov.ua/laws/show/1172-16.

2. Bulhakov R.V., Holovan V.H., Perspektyvna model informatsiinoho zabezpechennia systemy upravlinnia naukovymy proektamy u vyshchykh viiskovykh navchalnykh zakladakh. Zbirnyk naukovykh prats Viiskovoi akademii, 2019. № 1 (11). S. 130-136.

3. O. M. Perehuda, O. P. Cherkes, P. M. Piontkivskyi, O. V. Dziubenko Metodyka vyboru ta vprovadzhennia informatsiinoi systemy $\mathrm{v}$ diialnist vyshchoho viiskovoho navchalnoho zakladu. Zbirnyk naukovykh prats ZhVI. 2019. Vypusk 17. S. 41-51

4. VM Mikhailenko, TV Sichko Modeli i metody avtomatyzovanoi systemy upravlinnia rehionalnoho universytetskoho tsentru. Monohrafiia.-Vinnytsia: VNAU, 2014.-184 s.

5. Zakon Ukrainy "Pro naukovu ta naukovo-tekhnichnu diialnist"// [Elektronnyi resurs] Rezhym dostupu: http://zakon.rada.gov.ua/laws/show/848-19.

6. Horbachevskyi S., Orda M., Napriamky vykorystannia suchasnykh tekhnolohii v informatsiinomu zabezpechenni systemy viiskovoi osvity/ Zbirnyk naukovykh prats "Viiskova osvita”- №1 (41), - 2020. - S. 103-109.

\section{PЕЗЮМЕ}

Андрей Корецкий,
кандидат военных наук,
старший научный сотрудник
Национальный университет обороны Украины
имени Ивана Черняховского
Сергей Горбачевский,
кандидат технических наук,
старший научный сотрудник
Национальный университет обороны Украины
имени Ивана Черняховского
Людмила Наливайко,
Национальный университет обороны Украины
имени Ивана Черняховского

\section{Проблемные вопросы информационного обеспечения научной и научно- технической деятельности в ВВУЗ-е}


Рассмотрены структура информационного обеспечения (ИО) научной и научнотехнической деятельности в ВВУЗ-е, основные проблемные вопросы ИО и пути их решения.

Ключевые слова: информационная система; информационное обеспечение; научная и научно-техническая деятельность; высшие военные учебные заведение.

\title{
SUMMARY
}

\author{
Andrii Koretskyi, \\ $\mathrm{PhD}$ (military sciences), Senior Researcher \\ National Defence University of Ukraine \\ named after Ivan Chernyakhovskyi \\ Serhii Horbachevsky, \\ $\mathrm{PhD}$ (technical sciences), Senior Researcher \\ National Defence University of Ukraine \\ named after Ivan Chernyakhovskyi \\ Ludmila Nalyvaiko, \\ National Defence University of Ukraine \\ named after Ivan Chernyakhovskyi
}

\section{Problematic issues of information support of scientific and scientific and technical activities in higher military educational institutions}

Introduction. Information support is one of the main types of support for scientific and scientific-technical activities. Therefore, the analysis of the state of information support of scientific and scientific-technical activities and the elimination of problematic issues is an extremely important task. Information support of scientific and scientific-technical activity is a set of organizational and technical measures aimed at meeting the needs of scientific subjects in the information necessary for the creation of scientific (scientific and technical) products. Information support of scientific and scientific-technical activities is carried out by types of scientific and information activities, which include: collection, processing, storage, updating and dissemination of information.

Purpose - Analysis of problematic issues of information support of scientific activity and development of proposals for their solution.

Methods: The system of general scientific, theoretical and empirical research special methods, methodological analysis of the problem, systematization and generalization of scientific information concerning the nature and content of certain tasks, monitoring of existing systems were used to solve the set research problems, method of information data processing.

Results. Proposals for improving information support for scientific and scientific and technical activities in higher military educational institutions.

Originality. The article describes ways to improve information support for scientific and scientific and technical activities in higher military educational institution through the introduction of automations.

Conclusion. The current state of development of science requires the maximum introduction of modern technologies in the system of information support of scientific and scientific-technical activities in higher education. Such automation will improve the quality of management decisions on scientific and scientific-technical activities, as well as provide easy and convenient access of scientists to information, the ability to work together on research projects..

Key words: information system scientific and scientific-technical activities; higher military educational institutions; accounting automation. 